\title{
PENGARUH VLOGGER REVIEW SEBAGAI CELEBRITY ENDORSER TERHADAP PURCHASE INTENTION DENGAN BRAND IMAGE SEBAGAI INTERVENING VARIABEL PADA PRODUK KOSMETIK DAN PERAWATAN WAJAH
}

\author{
Kartika Rose Rachmadi \\ Dosen Fakultas Ekonomi \& Bisnis Universitas Islam Malang \\ Email : rose.kartika78@gmail.com
}

\begin{abstract}
Abstrak
Penelitian ini bertujuan untuk menguji pengaruh variabel vlogger review, brand image dan purchase intention pada produk kosmetik dan perawatan wajah. Penelitian ini menggunakan metode pendekatan kuantitatif dengan teknik path analysis.Sampel yang digunakan dalam penelitian ini berjumlah 100 responden dengan menggunakan teknik codalam pengambilan sampel. Hasil penelitian ini menunjukkan adanya pengaruh signifikan vlogger review terhadap brand image, brand image terhadap purchase intention, vlogger review terhadap purchase intention. Untuk brand image sebagai intervening variabel menunjukkan bahwa brand image tidak memediasi dan berpengaruh tidak signifikan saat menjadi intervening variabel pada variabel vlogger review terhadap purchase intention.

Kata kunci : Vlogger Review, Celebrity Endorser, Purchase Intention, Brand Image
\end{abstract}

\begin{abstract}
The purpose of this study is to examine the effect of vlogger review, brand image and purchase intention variables on cosmetic products and face treatment. This research uses quantitative approach method with path analysis technique. The sample used in this study amounted to 100 respondents by using co technique in sampling. The results of this study indicate a significant influence vlogger review of brand image, brand image to purchase intention, vlogger review of purchase intention. For brand image as intervening variable indicates that brand image doesn't mediate and have insignificant effect as variable intervening variable vlogger review to purchase intention.
\end{abstract}

Keyword : Vlogger Review, Celebrity Endorser, Purchase Intention, Brand Image

\section{PENDAHULUAN}

Teknologi informasi saat ini terus mengalami kemajuan. Hal ini menyebabkan konsumen dapat dengan mudah mengetahui informasi tentang suatu produk, terutama produk baru. Berkembangnya industri bisnis produk pada saat sekarang membuat banyak produsen mengunakan berbagai macam strategi untuk menarik para konsumennya. Kondisi ini menuntut perusahaan untuk tanggap dengan keinginan konsumen dan memberikan informasi yang jelas mengenai produknya agar mendapat tanggapan positif dari konsumen. Perusahaan dituntut untuk semakin peka terhadap keinginan konsumen dan mengkomunikasikan produk-nya secara baik dan efisien. Strategi pemasaran akan sangat berpengaruh terhadap penjualan khususnya dalam hal promosi. Dalam memasarkan produk, 
produsen harus mengunakan strategi untuk menarik perhatian konsumen salah satunya dengan iklan. Hal tersebut memerlukan kreativitas dalam pembuatan iklan tersebut entah dengan animasi dan grafik yang fresh atau bisa dilakukan melalui pemilihan celebrity endorsment produk yang memiliki kharisma dan kemampuan dalam memikat hati masyarakat yang melihat iklan tersebut. Strategi ini biasa disebut dengan endorsement for celebrity ataulebih akrab disebut celebrity endorsement.

Strategi dengan menggunakan celebrity endorsement saat ini sedang banyak dilakukan oleh beberapa perusahaan baik kecil,sedang maupun besar. Para pelaku usaha online juga banyak yang menggunakan jasa para selebriti dalam memasarkan produk-produk mereka. Tidak jarang para pelaku usaha tersebut rela mengeluarkan biaya fantastisuntuk membayar jasa para selebriti yang telah memasarkan produk lewat sosial media pribadi para selebriti tersebut. Celebrity endorsment dinilai cukup memberi pengaruh pada penjualan produk. Celebrity endorsment dipilih berdasarkan beberapa kriteria. Kriteria yang paling utama dalam memilih Celebrity endorsment adalah memiliki reputasi yang positif. Dengan reputasi yang positif dari Celebrity endorsment yang dipilih, maka akan memberikan citra yang baik bagi perusahaaan. Pemilihan Celebrity endorsment ini haruslah disesuaikan kecocokannya dengan produk yang akan dipromosikan melalui sosial media.

Permasalahan yang sering muncul saat ini adalah para konsumen biasa hanya melihat berdasarkan gambar. Selain itu para konsumen khususnya wanita banyak beberapa dari mereka yang tidak begitu memperhatikan soal brand image atau merek produk tersebut. Jika gambar dirasa lucu, warna sesuai dengan warna yang digemari, kemasan yang unik, tidak jarang para konsumen khususnya wanita mempunyai keinginan untuk membelinya. Akibatnya banyak dampak yang terjadi, di wajah akibatnya menimbulkan jerawat jika produk seperti bedak atau jika produk itu lipstik saat sudah membeli dan mencoba ternyata warna lipstik tidak cocok dengan bibir. Contoh permasalahan tersebut masih sebagian besar dari permasalahan para konsumen khususnya wanita setelah membeli produk kosmetik dan perawatan wajah secara online. Untuk dapat menghindari dan meminimalisir berbagai permasalahan yang akan atau sudah timbul dalam memilih produk kosmetik perawatan wajah yang akan dibeli, media sosial seperti Youtube dapat memberikan konten review yang dilakukan para pemakai atau kreator Youtube dalam hal ini sering kita sebut vlogger.

Menurut Annis Kiswalini (2013) Pengaruh Celebrity Endorser, Brand Image, Dan Kepercayaan Konsumen Terhadap Keputusan Pembelian. Hasil penelitian berdasarkan analisis regresi linier berganda menunjukan bahwa celebrity endorser, brand image, dan kepercayaan konsumen 
berpengaruh positif dan signifikan terhadap keputusan pembelian. Menurut Gevin Sepria Harly (2014) Pengaruh Endorsement Fashion Blogger Terhadap Minat Beli Merek Lokal Pada Tahun 2013-2014 (Studi Kasus Pada Fashion Blogger Evita Nuh)

Hasil penelitian yang didapat menunjukkan bahwa Endorsement Fashion Blogger yang terdiri dari sub variabel Visibility, Credibility, Attraction, dan Power mendapat tanggapan responden sebesar 83,72\% atau berada pada kategori sangat baik, sedangkan Minat Beli Merek Lokal mendapat tanggapan sebesar $75,4 \%$ atau termasuk pada kategori baik. Besarnya pengaruh Endorsement Fashion Blogger terhadap Minat Beli Merek Lokal pada blog Evita Nuh setelah dilakukan pengujian ulang melalui trimming adalah secara simultan variabel Credibili-ty dan Power memiliki pengaruh yang signifikan sebesar $37,4 \%$ sedangkan se-besar $62,6 \%$ dipengaruhi oleh variabel-variabel lain diluar penelitian ini.

Penelitian yang dilakukan oleh Muhartini Salim (2015) Pengaruh Celebrity Endorser terhadap Keputusan Pembelian Produk di Indonesia . Hasil penelitian menunjukkan bahwa pengaruh positif dukungan vlogger terhadap Keputusan Pembelian. Semua indikator dukungan vlogger secara simultan dapat mempengaruhi keputusan pembelian.

Penelitian yang dilakukan oleh Adellya Nurmalasari (2015) Analisis Pengaruh Creative Promotion, Visual Merchandising dan Harga Pada Keputusan Pembelian Produk Ritel Fashion (Studi Kasus pada Konsumen PT. Mitra Adi Perkasa). Hasil dari penelitian ini adalah Creative promotion terbukti berpengaruh positif dan signifikan terhadap keputusan pembelian, yang dapat dibuktikan dari hasil uji - t sebesar 2,256. Visual merchandising terbukti berpengaruh positif dan signifikan terhadap keputusan pembelian, yang dapat dibuktikan dari hasil uji - t sebesar 4,252. Harga terbukti berpengaruh positif dan signifikan terhadap keputusan pembelian, yang dapat dibuktikan dari hasil uji - t sebesar 4,059.

Menurut Veronika (2016) Pengaruh Iklan dan Brand Image Terhadap Minat Beli Konsumen, Dengan Brand Image Sebagai Variabel Mediasi (Kasus Calon Konsumen Shampoo Dove di Pusat Perbelanjaan: Gardena Departemen Store \& Supermarket Yogyakarta). Hasil Penelitian menunjukkan bahwa (1) iklan dan brand image mempunyai pengaruh positif terhadap minat beli konsumen secara sendiri-sendiri, (2) iklan berpengaruh positif terhadap brand image, (3) brand image tidak memediasi pengaruh iklan terhadap minat beli konsumen. Yan Bayu Bramantya (2016) Pengaruh Celebrity Endorser dan Brand Image Terhadap Keputusan Pembelian Yamaha Jupiter MX Di Kota Denpasar Komenk sebagai celebrity endorser dan brand image berpengaruh secara simultan terhadap keputusan pembelian Yamaha Jupiter MX di Kota Denpasar, hasil pengujian nilai Fhitung $(204,375)$ dan nilai signifikansi 0,000. Secara parsial Komenk 
sebagai Celebrity endorser lebih dominan mempengaruhi keputusan pembelian Yamaha Jupiter MX di Kota Denpasar dibandingkan dari brand image. Irma Kurniasari (2017) Pengaruh Country Image dan Beauty Vlogger Review Terhadap Purchase Konsumen Kosmetik Korea (Studi Kasus Pada Produk kosmetik.kr). Hasil temuan dari penelitian ini menunjukan bahwa 1) Country image berpengaruh secara signifikan terhadap purchase intention pada situs Produk kosmetik.kr dan 2). Beauty vlogger review berpengaruh secara signifikan terhadap purchase intention pada situs Produk kosmetik.kr Yulia Widhayanti (2017) Pengaruh Brand Ambassador, Sales Promotion, Dan Word Of Mouth Terhadap Keputusan Pembelian Melalui Brand Image (Studi Kasus Mahasiswa UNDIP untuk Produk Luwak White Koffie). Hasil penelitian menunjukkan bahwa brand ambassador, sales promotion, dan word of mouth berpengaruh positif dan signifikan terhadap brand image. Semakin tinggi penilaian terhadap brand ambassador, sales promotion, dan word of mouth semakin tinggi pula penilaian brand image Luwak White Koffie. Brand ambassador, word ofmouth, dan brand image berpengaruh positif dan signifikan terhadap keputusan pembelian. Semakin tinggi penilaian terhadap brand ambassador, word of mouth, dan brand image maka semakin tinggi keputusan pembelian Luwak White Koffie.

\section{KAJIAN TEORI}

Teori pemasaran Kotler dan teori promosi Lamb, penjelasan tentang vlog, vlogging dan vlogger dapat dijelaskan secara terperinci dan mudah dipahami. Pada teori pemasaran Kotler disebutkan bahwa pemasaran adalah proses sosial yang inti salah satu dari kegiatannya yaitu komunikasi. Inti kegiatan pemasaran menurut Kotler (2014) yaitu komunikasi dapat disangkut pautkan dengan vlog karena pada saatvlogger membuat sebuah vlog melalui vlogging disitulah tercipta komunikasi antara vlogger dan viewers maupun subscribers. Sedangkan pada teori Lamb disebutkan tujuan dari promosi antara lain informing, persuasif dan reminding dimana dari ketiga tujuan promosi menurut Lamb, Hair dan McDaniel (dalam Bob Sabran 2012) merupakan bagian dari vlogger. Para vlogger yang mendapat tugas review produk mencoba memberikan informasi produk dari konten yang sudah dia buat. Melalui konten tersebut secara otomatis memberikan persuasif kepada para viewers untuk mencoba bahkan membeli produk. Karena review produk sudah masuk konten vlogger tersebut maka dapat dijadikan reminding kepada viewers dan subscriberss dari masing-masing vlogger tersebut.

Pengertian selebrity menurut Schiffman dan Kanuk (2015) adalah bintang film, artis, model, pembawa acara, entertainer, olahragawan, dan orang-orang masyarakat. Perusahaan lebih sering menggunakan selebriti 
untuk mendukung produknya dalam suatu iklan (celebrity endorser). Istilah celebrity endorser mulai dikenal masyarakat sejak media sosial seperti Instagram muncul. Para endorser khususnya selebriti ini membantu memasarkan produk dari masing-masing produsen tentunya dengan tujuan memperoleh keuntungan dan agar produk mereka lebih dikenal oleh masyarakat. Endorsment celebrity ini biasanya mengupload produk yang mereka pasarkan dalam bentuk gambar maupun video durasi singkat. Keunikan dan kreatifitas dari celebrity dalam mengendorse produk menjadi nilai plus tersendiri dalam memasarkan produk seperti foto yang diambil dan caption yang dicantumkan.

Menurut Setiadi (2013) Citra merek mengacu pada skemamemori akan sebuah merek, yang berisikan interpretasi konsumen atas atribut,kelebihan, penggunaan, situasi, para pengguna, dan karakteristik pemasardan/atau karakteristik pembuat dari produk/merek tersebut. Citra merek (brand image) merupakan representasi dari keseluruhanpersepsi terhadap merek dan dibentuk dari informasi dan pengalaman masa laluterhadap merek itu. Citra terhadap merek berhubungan dengan sikap yangberupa keyakinan dan preferensi terhadap suatu merek. Konsumen yangmemiliki citra yang positif terhadap suatu merek, akan lebih memungkinkanuntuk melakukan pembelian.Citra merek adalahapa yang konsumen pikirkan dan rasakan ketika mendengar atau melihat namasuatu merek.

Pengertian minat beli menurut Howard yang dikutip dalam (Durianto dan Liana, 2013) adalah minat beli merupakan sesuatu yang berhubungan dengan rencana konsumen untuk membeli produk tertentu serta berapa banyak unit produk yang dibutuhkan pada periode tertentu. Dapat dikatakan bahwa minat beli merupakan pernyataan mental dari dari konsumen yang merefleksikan rencana pembelian sejumlah produk dengan merek tertentu.

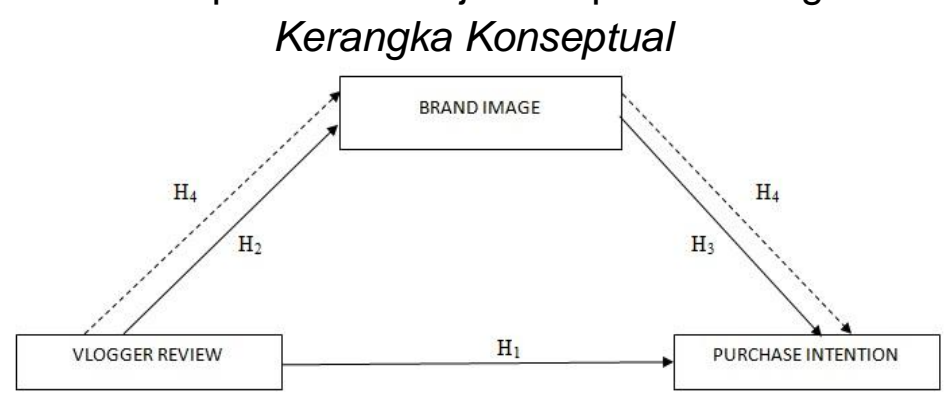

Hipotesis Penelitian

1. $\mathrm{H}_{1}=$ Terdapat pengaruh antara vlogger review dan brand image

2. $\mathrm{H}_{2}=$ Terdapat pengaruh antara brand image dan purchase intention

3. $\mathrm{H}_{3}=$ Terdapat pengaruh antara vlogger review dan purchase intention

4. $\mathrm{H}_{4}=$ Terdapat pengaruh antara vlogger review, brand imagedan purchase intention 


\section{METODE PENELITIAN}

Jenis penelitian yang digunakan dalam penelitian ini adalah penelitian ini menggunakan penelitian kuantitatif dengan pendekatan survey, dan menggunakan kuisioner sebagai alat pengumpulan data. Kuesioner dalam penelitian ini menggunakan skala Likert.. Lokasi penelitian dalam penelitian ini dilakukan secara online melalui situs Youtube dan offline dengan sebar kuisionerdi Universitas Islam Malang.

Waktu penelitian berlangsung selama kurang lebih 4 bulan,mulai bulan Januari sampai dengan April 2018. Populasi dalam penelitian ini adalah mahasiswi FE semester 5,6 dan 7 di Universitas Islam Malang. Dikarenakan jumlah populasi tidak diketahui secara pasti maka untuk mengetahui besarnya sampel yaitu menggunakan teknik co. berdasarkan hal tersebut, peneliti menyeleksi dengan menyaring kuesioner yang ada, apabila orang-orang tersebut diketahui. Misalnya digunakan sampel untuk estimasi nilai rata-rata. Jika digunakan untuk mengestimasi $\mu$, kita dapat (1a)\% yakni error tidak melebihi nilai pertama e tertentu apabila ukuran sampelnya tidak diketahui. sampel yang didapat yaitu sebesar 96,04 untuk lebih memudahkan maka dibulatkan menjadi 100 responden. Jadi penelitian ini menggunakan 100 responden untuk dijadikan sampel penelitian

\section{HASIL ANALSIS DATA}

Berdasarkan hasil pengujian normalitas dapat nilai signifikansinya lebih besar dari $\alpha=0,05$ dengan nilai sebesar 0,517. Dengan demikian data tang tersaji diatas berdistribusi normal. hasil pengujian multikolinieritas yang disajikan dapat dilihat bahwa nilai tolerance Vlogger review $(\mathrm{X})$ dan Brand image $(Y)$ lebih besar dari 0,10 dengan nilai sebesar 0,569. Sementara itu nilai VIF Vlogger review (X) dan Brand image $(Y)$ lebih kecil dari 10,00 dengan nilai sebesar 1,757. Maka dapat disimpulkan bahwa dari hasil pengujian data diatas tidak terjadi multikolinieritas. Berdasarkan hasil pengujian heteroskedastisitas nilai signifikansi variabel Vlogger review sebesar 0,520 lebih besar dari 0,05 dan variabel Brand image dengan nilai sebesar 0,676 lebih besar dari 0,05. Sesuai dasar pengambila keputusan uji heteroskedastisitas dapat disimpulkan bahwa dari hasil pengujian data diatas tidak terjadi adanya heteroskedastisitas, sehingga dapat dianalisa lebih lanjut.

Pengaruh variabel vlogger review $(\mathrm{X})$ terhadap brand image $(\mathrm{Y})$ ditunjukkan oleh tabel 4.15 dengan paparan sebagai berikut :

\section{Tabel 4.15 Hasil Perhitungan secara Parsial}

\section{Coefficients $^{\mathrm{a}}$}

\begin{tabular}{|l|l|l|l|l|l|}
\hline \multirow{2}{*}{ Model } & \multicolumn{2}{|l|}{$\begin{array}{l}\text { Unstandardized } \\
\text { Coefficients }\end{array}$} & \multicolumn{2}{l|}{$\begin{array}{l}\text { Standardized } \\
\text { Coefficients }\end{array}$} & \\
\cline { 2 - 5 } & $\mathrm{B}$ & Std. Error & Beta & $\mathrm{t}$ & Sig. \\
\hline 1 (Constant) & 5.744 & 2.028 & & 2.831 & .006 \\
VLOGGER_X & .491 & .057 & .657 & 8.616 & .000 \\
\hline
\end{tabular}

a. Dependent Variable: BRANDIMAGE_Y 
Berdasarkan tabel coefficients di atas, dapat diketahui bahwa variabel vlogger review mempunyai nilai signifikansi sebesar 0,000. Jika dibandingkan dengan $\alpha=0,05$ maka nilai signifikansi <nilai $\alpha(0,000<0,05)$ $\mathrm{H}_{0}$ ditolak $\mathrm{H}_{\mathrm{a}}$ diterima. Dengan demikian besarnya beta (koefisien jalur) variabel vlogger review $(\mathrm{X})$ terhadap brand image $(\mathrm{Y})$ adalah 0,657.

Pengaruh variabel brand image $(Y)$ terhadap purchase intention $(Z)$ ditunjukkan oleh tabel 4.17 dengan paparan sebagai berikut :

\section{Tabel 4.17 Hasil Perhitungan secara Parsial}

\section{Coefficients $^{\mathrm{a}}$}

\begin{tabular}{|c|c|c|c|c|c|}
\hline \multirow[b]{2}{*}{ Model } & \multicolumn{2}{|c|}{$\begin{array}{l}\text { Unstandardized } \\
\text { Coefficients }\end{array}$} & \multirow{2}{*}{$\begin{array}{l}\text { Standardized } \\
\text { Coefficients } \\
\text { Beta } \\
\end{array}$} & \multirow[b]{2}{*}{$\mathrm{t}$} & \multirow[b]{2}{*}{ Sig. } \\
\hline & $B$ & Std. Error & & & \\
\hline $\begin{array}{ll}1 & \text { (Constant) } \\
& \text { BRANDIMAGE_Y }\end{array}$ & $\begin{array}{l}13.210 \\
.201\end{array}$ & $\begin{array}{l}1.633 \\
.070\end{array}$ & .280 & $\begin{array}{l}8.088 \\
2.883\end{array}$ & $\begin{array}{l}.000 \\
.005\end{array}$ \\
\hline
\end{tabular}

a. Dependent Variable: PURCHASE_Z

Sumber : Hasil Output SPSS 16 yang telah diolah, 2018

Berdasarkan tabel coefficients di atas, dapat diketahui bahwa variabel vlogger review mempunyai nilai signifikansi sebesar 0,005. Jika dibandingkan dengan $\alpha=0,05$ maka nilai signifikansi <nilai $\alpha(0,005<0,05)$. Dengan demikian besarnya beta (koefisien jalur) variabel brand image $(Y)$ terhadap purchase intention (Z) adalah 0,280.

Pengaruh variabel vlogger review $(\mathrm{X})$ terhadap purchase intention

Berdasarkan tabel coefficients di atas, dapat diketahui bahwa variabel vlogger review mempunyai nilai signifikansi sebesar 0,000. Jika dibandingkan dengan $\alpha=0,05$ maka nilai signifikansi <nilai $\alpha(0,000<0,05)$. Dengan demikian besarnya beta (koefisien jalur) variabel vlogger review $(\mathrm{X})$ terhadap purchase intention (Z) adalah 0,496.

\section{PEMBAHASAN}

Pada perhitungan struktural I, variabel vlogger review (X) berpengaruh terhadap brand image $(\mathrm{y})$. besarnya pengaruh vlogger review terhadap brand image adalah 0,657 atau 65,7\%. Hal ini berarti semakin jujur seorang vlogger dalam me-review maka akan membuat kepercayaan viewers terhadap vlogger review meningkat, sehingga akan mendorong sikap atau kesan penikmat vlog yang lebih baik terhadap merek yang didukungnya. Seorang vlogger review yang dianggap sebagai ahli pada saat mempresentasikan atau me-review suatu produk akan lebih persuasif dalam mengubah pendapat viewers tentang suatu merek. Hal ini sesuai dengan teori Shimp (Shimp, 2014) yang menyatakan bahwa jika celebrity endorser sebagai sumber pesan dianggap kredibel, maka akan mempengaruhi sikap (attitudes) atau kesan konsumen secara positif terhadap merek yang didukungknya. Selain itu penggunaan celebrity endorser akan memengaruhi kesan konsumen secara positif terhadap merek yang didungkungnya, sehingga konsumen akan 
mempertimbangkannya dalam proses pembelian dan membuat konsumen dipengaruhi untuk membeli tanpa ada paksaan (Shimp, 2013). Selebriti secara probadi memakai sebuah produk atau kasa dalam kehidupannya sehari-hari, kemudian memberikan kesaksian atau membuktikan kualitas dan manfaat produk yang dikonsumsinya, sesuai dengan peran celebrity endorsment dalam Teori Schiffman dan Kanuk (2015).

Pada perhitungan struktural II, variabel brand image $(\mathrm{Y})$ berpengaruh terhadap purchase intention (Z). Besarnya pengaruh brand image terhadap purchase intention adalah 0,280 atau $28 \%$. Hal ini dapat diartikan bahwa semakin baik citra merek atau brand image maka dapat meningkatkan minat beli dari para calon konsumen. Sebagai mana telah disebutkan dalam teori yang diungkapkan oleh Simamora (2012) faktor-faktor yang dipertimbangkan oleh pembeli pada saat membeli produk adalah atribut produk yang didalamnya menyangkut tentang kemasan produk, harga, kualitas, kelengkapan fungsi (fitur), dan layanan purna jual. Kemasan yang ada pada produk kosmetik dan perawaran wajah masa kini termasuk menarik dan bersifat informatif. Menurut Setiadi (2013) Citra merek mengacu pada skema memori akan sebuah merek, yang berisikan interpretasi konsumen atas atribut, kelebihan, penggunaan, situasi, para pengguna, dan karakteristik pemasar dan/atau karakteristik pembuat dari produk/merek tersebut. Menurut Kotler (2016) citra merek harus dibangun melalui seluruh media yang ada serta berkelanjutan dan pesan tersebut dapat disampaikan melalui lambang, media atau visual, suasana, serta acara. Identitas suatu merek adalah pesan yang disampaikan oleh suatu merek melalui bentuk tampilan produk, nama, simbol, iklan, dsb.

Pada perhitungan struktural III, variabel vlogger review (X) berpengaruh terhadap purchase intention ( $\mathrm{Z})$. Besarnya pengaruh brand image terhadap purchase intention adalah 0,496 atau 49,6\%. Hal ini membuktikan bahwa seorang vloggerpada saat mereview konten sekaligus memasarkan produk akan berpengaruh terhadap minat beli para calon konsumen. Semakin menarik para vlogger dalam mengemas konten akan semakin tinggi pula minat beli para calon konsumen. Menurut Schiffman dan Kanuk (2015), menjelaskan bahwa pengaruh eksternal, kesadaran akan kebutuhan, pengenalan produk dan evaluasi alternatif adalah hal yang dapat menimbulkan minat beli konsumen. Pengaruh eksternal ini terdiri dari usaha pemasaran dan faktor sosial budaya. Usaha pemasaran yang diungkap menurut teori tersebut salah satu nya usaha pemasaran online yang memerlukan seorang endorsment dalam hal ini seorang vlogger review dalam memasarkan produk.

Pada perhitungan stuktural IV, variabel brand image (Y) dan vlogger review $(\mathrm{X})$ berpengaruh terhadap purchase intention $(\mathrm{Z})$. Besarnya pengaruh brand image terhadap purchase intention adalah 0,018 atau $1,8 \%$. Hal ini membuktikan bahwa brand image hanya mempengaruhi $1,8 \%$ terhadap para calon konsumen. Walaupun hanya 1,8\% bukan berarti tidak mempengaruhi hanya saja peran brand image disini tidak terlalu berpengaruh kepada para calon konsumen akan sebuah produk. Beberapa dari calon konsumen tidak begitu memperhatikan brand image, dirasa produk kosmetik dan perawatan wajah tersebut mampu membuat kulit 
sehat dan cukup memenuhi kebutuhan maka calon konsumen itu sendiri mempunyai minat akan pembelian produk tersebut. Sedangkan besarnya pengaruh vlogger review terhadap purchase intention adalah sebesar 0,438 atau $43,8 \%$. Hal ini membuktikan bahwa seorang vlogger pada saat mereview konten sekaligus memasarkan produk akan berpengaruh terhadap minat beli para calon konsumen. Semakin menarik para vlogger dalam mengemas konten akan semakin tinggi pula minat beli para calon konsumen. Hasil penelitian ini didukung oleh penelitian serupa oleh Veronika (2016) yang menunjukkam bahwa brand image tidak mengintervening antara vlogger review dan purchase intention. Artinya bahwa pengaruh langsung antara vlogger review terhadap purchase intention para calon konsumen lebih tinggi daripada pengaruh tidak langsung antara vlogger review terhadap purchase intention melalui brand image. Menurut Schiffman dan Kanuk (2015), menjelaskan bahwa pengaruh eksternal, kesadaran akan kebutuhan, pengenalan produk dan evaluasi alternatif adalah hal yang dapat menimbulkan minat beli konsumen. Pengaruh eksternal ini terdiri dari usaha pemasaran dan faktor sosial budaya. Usaha pemasaran yang diungkap menurut teori tersebut salah satu nya usaha pemasaran online yang memerlukan seorang endorsment dalam hal ini seorang vlogger review dalam memasarkan produk.

\section{SIMPULAN DAN SARAN}

Berdasarkan hasil estimasi dan uji hipotesis masing-masing variabel eksogen terhadap variabel endogen diperoleh hasil sebagai berikut:

1. Vlogger review berpengaruh prositif dan signifikan terhadap brand imagepada produk kosmetikdan perawatan wajah.

2. Brand image berpengaruh positif dan signifikan terhadap purchase intention pada produk kosmetikdan perawatan wajah.

3. Vlogger review berpengaruh positif dan signifikan terhadap purchase intention pada produk kosmetikdan perawatan wajah.

4. Brand image tidak berpengaruh secara signifikan terhadap purchase intention, beda hal nya dengan vlogger review yang berpengaruh signifikan terhadap purchase intention. Oleh karena itu brand image tidak memediasi sebagai variabel intervening pengaruh antara vlogger review terhadap purchase intention pada produk kosmetikdan perawatan wajah.

Dengan demikian dapat disimpulkan bahwa vlogger review sebagai celebrity endorser dalam menyampaikan informasi berupa konten pada channel Youtube dapat menimbulkan sebuah purchase intention kepada para calon konsumen secara langsung tanpa melalui brand image.

\section{DAFTAR PUSTAKA}

Aaker, D. 2014. Building Strong Brands (A. Baderi, Trans). Jakarta: Bumi Boyd, Walker, Larreche. 2010. Manajemen Pemasaran Suatu Pendekatan Edisi 2 Jilid 1. Jakarta: Erlangga 
Basu Swastha, Dharmesta dan Irawan. 2012. Manajemen Pemasaran Modern. Yogyakarta: Liberty Offset

Bayu, Yan. 2016. Pengaruh Celebrity Endorser dan Brand Image Terhadap Keputusan Pembelian Yamaha Jupiter MX Di Kota Denpasar. Jurnal. Diakses Tanggal 28 Oktober 2017

Durianto dan Liana. 2013. Strategi Menaklukan Pasar Melalui Riset, Ekuitas dan Perilaku. Jakarta: PT Gramedia Pustaka

Ferdinand, Augusty. 2014. Metode Penelitian Manajemen. Semarang: Badan Penerbit Universitas Diponegoro

Ghozali, Imam. 2016. Apilkasi Analisis Multivariate Dengan Program IBM SPSS 23. Semarang: Badan Penerbit Universitas Diponegoro

Kertamukti, Rama. 2015. Strategi Dalam Periklanan. Jakarta: PT. Raka Grafindo

Kiswalini, Annis. 2013. Pengaruh Celebrity Endorser, Brand Image, Dan Kepercayaan Konsumen Terhadap Keputusan Pembelian. Jurnal. Diakses Tanggal 3 November 2017

Kotler, Phillip dan Kevin Lane Keller. 2012. Marketing Pemasaran Jilid Kedua. Jakarta: Erlangga

Kotler, Phillip P., Bowen, John T \& Makens, James. 2014. Marketing For Hospitality and Tourism: Sixth Edition. London: Pearson Education Limited

Kotler, Phillip \& Gary Amstrong. 2014. Principle Of Marketing $15^{\text {th }}$ Edition. New Jersey: Pearson Prentice Hall

Kotler, Phillip dan Kevin L. Keller. 2016. Marketing Management 16 Edition. New Jersey: Pearson Prentice Hall

Kurniasari, Irma. 2017. Pengaruh Country Image dan Beauty Vlogger Review Terhadap Purchase Konsumen Kosmetik Korea (Studi Kasus Pada Produk kosmetik.kr). Jurnal. Diakses Tanggal 12 Oktober 2017

Nurmalasari, Adellya. 2015. Analisis Pengaruh Creative Promotion, Visual Merchandising dan Harga Pada Keputusan Pembelian Produk Ritel Fashion (Studi Kasus pada Konsumen PT. Mitra Adi Perkasa). Jurnal. Diakses Tanggal 3 November 2017

Salim, Muhartini. 2015. Pengaruh Celebrity Endorser terhadap Keputusan Pembelian Produk di Indonesia. Jurnal. Diakses Tanggal 12 Oktober 2017

Schiffman, Leon G. dan Leslie Lazar Kanuk. 2010. Consumer Behavior Tenth Edition. New Jersey: Pearson Education.

Sepria, H, Gevin. 2014. Pengaruh Endorsement Fashion Blogger Terhadap Minat Beli Merek Lokal Pada Tahun 2013-2014 (Studi Kasus Pada Fashion Blogger Evita Nuh). Jurnal. Diakses Tanggal 3 November 2017

Shimp, Terence. 2014. Komunikasi Terpadu Dalam Periklanan Promosi. Jakarta: Salemba Empat

Siregar, Syofian. 2013. Statistik Parametrik Untuk Penelitian Kuantitatif. Jakarta: PT Fajar Interpratama Mandiri

Suyanto. 2013. Multimedia Alat Untuk Meningkatkan Keunggulan Bersaing. Jakarta: PT. Elex Media Komputindo 
Sugiyono. 2016. Metode Penelitian Kuantitatif, Kualitatif dan R\&D. Bandung: PT Alfabet

Veronika. 2016. Pengaruh Iklan dan Brand Image Terhadap Minat Beli Konsumen, Dengan Brand Image Sebagai Variabel Mediasi (Kasus Calon Konsumen Shampoo Dove di Pusat Perbelanjaan: Gardena Departemen Store \& Supermarket Yogyakarta). Jurnal. Diakses Tanggal 28 Oktober 2017

Widhayanti, Yulia. 2017. Pengaruh Brand Ambassador, Sales Promotion, Dan Word Of Mouth Terhadap Keputusan Pembelian Melalui Brand Image (Studi Kasus Mahasiswa UNDIP untuk Produk Luwak White Koffie). Jurnal. Diakses Tanggal 28 Oktober 2017

http://id.wikipedia.org

http://www.kominfo.go.id/

http://wearesocial.com/ 